Figueiredo, J.P.; Schwartz, G.M.; Pereira, L.M.; Tavares, G.H.; Dias, V.K. Ecoturismo e sustentabilidade: pesquisa sobre aspectos subjetivos. Anais do VIII Congresso Nacional de Ecoturismo e do IV Encontro Interdisciplinar de Ecoturismo em Unidades de Conservação. Revista Brasileira de Ecoturismo, São Paulo, v.4, n.4, 2011, p. 557.

\title{
ECOTURISMO E SUSTENTABILIDADE: PESQUISA SOBRE ASPECTOS SUBJETIVOS
}

\section{Juliana de Paula Figueiredo*, Gisele Maria Schwartz*, Leonardo Madeira Pereira*, Giselle Helena Tavares*, Viviane Kawano Dias ${ }^{* \star}$}

*Universidade Estadual Paulista Júlio de Mesquita Filho - Câmpus Rio Claro, ${ }^{*}$ Centro Universitário de Jales

E-mails: julianapfig@hotmail.com, schwartz171@yahoo.com.br, lelmadeira@yahoo.com.br, gi_htavares@yahoo.com.br,vivikdias@yahoo.com.br

As atividades desenvolvidas no setor do Ecoturismo têm merecido a atenção de pesquisadores em diferentes campos do conhecimento. Entretanto, por ser este um tema bastante amplo, envolvendo diversas variáveis de difícil controle científico, muitos aspectos são ainda inexplorados na literatura, entre eles, as questões referentes às subjetividades envolvidas durante as vivências e suas ressonâncias na perspectiva da sustentabilidade e da adequação do mercado ecoturístico, no que se refere ao atendimento aos praticantes. Este aspecto foi o gerador de interesse deste estudo, de natureza qualitativa, o qual objetivou investigar as sensações presentes durante uma atividade ecoturística e as ressonâncias destas experiências realizadas em ambiente natural, no sentido do desenvolvimento de noções sobre sustentabilidade. $\mathrm{O}$ estudo foi referente à união de pesquisas bibliográfica e exploratória, para a qual foi utilizado como instrumento um questionário contendo perguntas abertas, aplicado a uma amostra intencional composta por 60 participantes, de ambos os sexos, com idades variando entre 18 e 22 anos, participantes de uma atividade de Ecoturismo, referente à visitação em caverna e rapel. Os dados foram analisados de forma descritiva, utilizando a Técnica de Análise de Conteúdo Temático e indicam que as sensações mais presentes envolviam a ansiedade e o prazer. O medo se torna um atrativo envolvido nestas atividades e o prazer da superação desse medo se dá com o sucesso na realização dessa atividade. Os participantes evidenciaram maior compromisso com a natureza a partir destas vivências, no sentido de que as mesmas aumentam a conscientização ambiental e a atenção com aspectos ligados à sustentabilidade. Com base nessas premissas, tornam-se necessárias outras pesquisas, no sentido de ampliar as reflexões acerca do potencial do ecoturismo na disseminação de atitudes e condutas pró-ambientais e sustentabilidade.

Palavras-chave: Ecoturismo; Sustentabilidade; Subjetividade. 